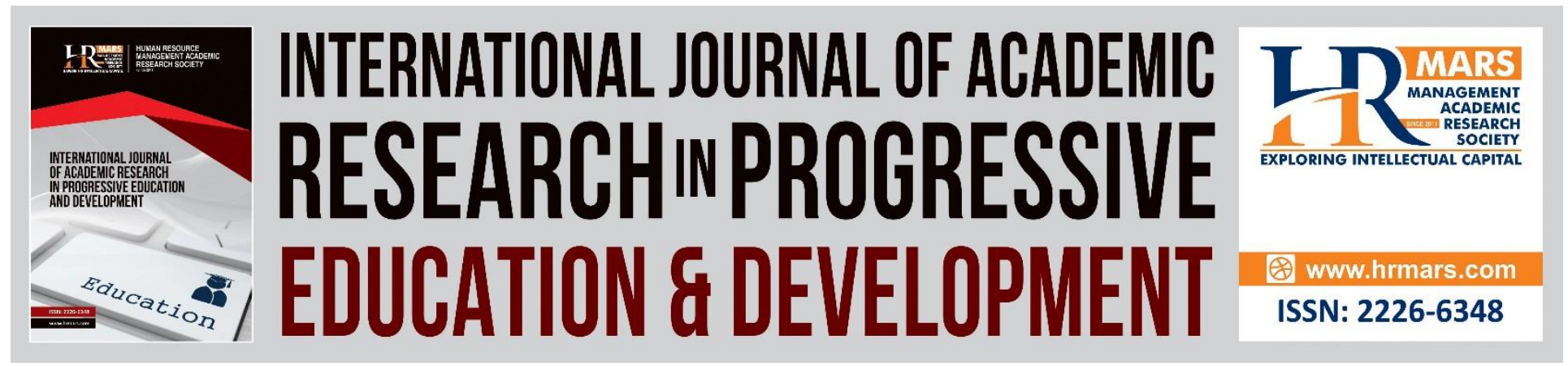

\title{
Malaysian Preschool Children Global Readiness in Diversity and Multiculturalism Knowledge
}

Azizah Zain, Jamilah Mohd Basir, Mazlina Che Mustafa

To Link this Article: http://dx.doi.org/10.6007/IJARPED/v9-i4/8457

DOI:10.6007/IJARPED/v9-i4/8457

Received: 03 November 2020, Revised: 28 November 2020, Accepted: 15 December 2020

Published Online: 28 December 2020

In-Text Citation: (Zain et al., 2020)

To Cite this Article: Zain, A., Basir, J. M., \& Mustafa, M. C. (2020). Malaysian Preschool Children Global Readiness in Diversity and Multiculturalism Knowledge. International Journal of Academic Research in Progressive Education and Development, 9(4), 164-175.

Copyright: (C) 2020 The Author(s)

Published by Human Resource Management Academic Research Society (www.hrmars.com)

This article is published under the Creative Commons Attribution (CC BY 4.0) license. Anyone may reproduce, distribute, translate and create derivative works of this article (for both commercial and non-commercial purposes), subject to full attribution to the original publication and authors. The full terms of this license may be seen

at: http://creativecommons.org/licences/by/4.0/legalcode

Vol. 9(4) 2020, Pg. 164 - 175

http://hrmars.com/index.php/pages/detail/IJARPED

JOURNAL HOMEPAGE

Full Terms \& Conditions of access and use can be found at http://hrmars.com/index.php/pages/detail/publication-ethics 


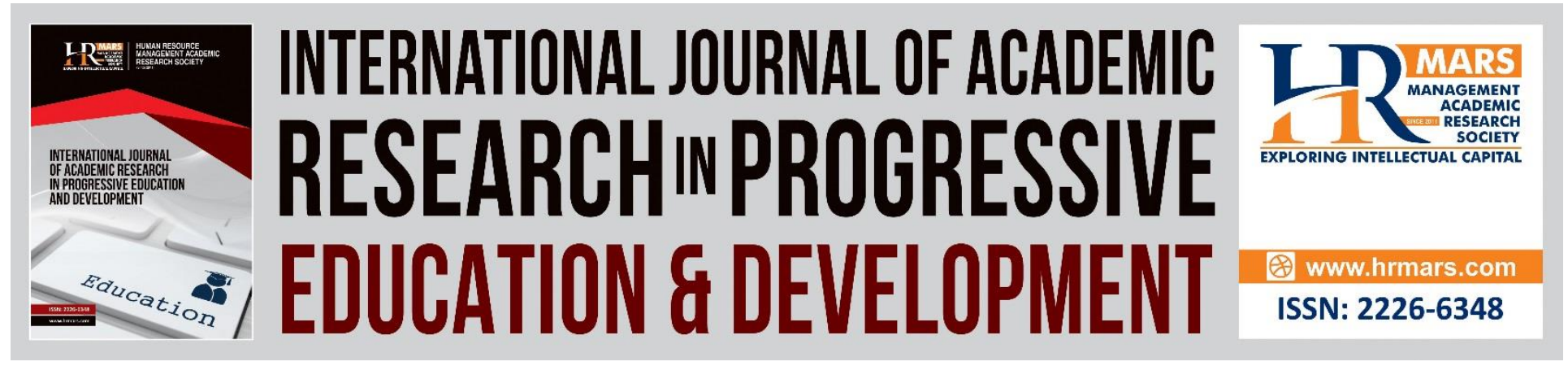

\title{
Malaysian Preschool Children Global Readiness in Diversity and Multiculturalism Knowledge
}

\author{
Azizah Zain, Jamilah Mohd Basir, Mazlina Che Mustafa \\ Faculty of Human Development, Sultan Idris University of Education (UPSI), Malaysia,
}

\begin{abstract}
The purpose of this study is to explore preschool children global readiness in diversity and multiculturalism knowledge. Four aspects of basic knowledge assessed are related to diversity and multiculturalism. These are cultural knowledge of different ethnic groups, geographical knowledge of different countries, mutual respect towards others and communication skills with friends from various countries. The study uses a set of written questionnaire for six years old preschool children. This quantitative study is conducted by analysing the percentage of children who can answer every aspect of diversity and multiculturalism questions. Seven hundred fiftyfour preschool children were randomly chosen from four zones in East Malaysia as a sample for this study. The main highlight is that out of four aspects in the diversity and multiculturalism, children recognise mutual respect towards others have the highest mean (mean=.914). Secondly, by discerning the language used to communicate with friends from other countries (mean=.911), children know the culture of different ethnic groups (mean=.855). The lowest mean are children fathom the knowledge for the geography of different countries (mean=.655 (mean=665) The purpose of this study is to help preschool teachers to apply global readiness education in diversity and multiculturalism knowledge. Therefore, the preschool children are not only equipped with academic skills but competent to be future global players. Thus, the knowledge of diversity and multiculturalism imparted plenty of adaptive skills for the outside world in line with 21st-century learning.
\end{abstract}

Keywords: Diversity, Multiculturalism, Global Readiness, Knowledge, Preschool.

\section{Introduction}

Malaysia is well known for its multicultural background (Fam, 2015). The majority of people were amalgamating into one cohesive troop of peoples in a colourful weave of a pattern of its different strands. Malaysia's population consists of various ethnicity and genetic heritage. However, society generally tolerates each other with no multiracialism strife, which makes Malaysia is a relatively successful, prosperous, and harmonious society.

According to the International Federation of Library Associations and Institutions (IFLA), multiculturalism is the coexistence of diverse cultures, which include racial, religious, or cultural 
groups. It is noticeable in language, behaviours, and thinking styles. Global define as the global world and also refers to something broad and unlimited to something (Dewan Kamus, 2013). In an indefinite context, global includes social, cultural, economic and political aspects worldwide. (UNESCO, 2015)

The connection between multiculturalism and education in Malaysia is crucial in determining the standpoint of people in educational institutions. The importance of learning about other cultures and languages regulate multicultural education as a requirement for all early childhood education programs. Therefore, school often endorse as part of earlier dimension to empowering diversity and multiculturalism even among the pre-schoolers.

Education in Malaysia is a continuous effort towards expanding the potential of individuals in a comprehensive and integrated way to create a balanced and harmonious human being in terms of intellectual, spiritual, emotional and physical (Malaysia Education Blueprint, 2012). Multifarious improvements have been made, and the education system in Malaysia is evolving in tandem with changes and current issues. The development and reinforcement of the educational system are aimed at achieving quality educational aspirations.

The primary goal of preschool education is to broaden the potential of preschool children. This is achieved by using comprehensive and integrated way in the physical, emotional, spiritual, intellectual and social aspects through a safe, nourishing, entertaining and engaging learning environment that is fun, creative and meaningful (Ministry of Education, 2017). Therefore, the best way to inculcate diversity and multiculturalism knowledge among children is to integrate global readiness education into teaching in the classroom. Global readiness related education can educate our children, thus help future generations to control their lives and achieve future progress.

Global readiness determines to produce sustainable think-tank children who are responsive to the multicultural society in daily life. This could be achieved by applying knowledge, skills and values gained through the elements of cultural diversity, information and technology skills, language, thinking skills, financial literacy, security, communication and environment.

Through global readiness education, students have the opportunity to make choices wisely and embrace the diversity of our multicultural society. Multiculturalism is part of a more significant human-rights revolution (Kymlicka, 2012). It often foresees similar character by convergence related to ethnicity, gender, indigenous heritage, national origin, race, religion and other social identities. Therefore, global readiness provides a platform to enhance their comprehension and awareness of their social, economic and environmental responsibilities, thus edify them into a global player. 
INTERNATIONAL JOURNAL OF ACADEMIC RESEARCH IN PROGRESSIVE EDUCATION AND DEVELOPMENT

Vol. 9, No. 4, 2020, E-ISSN: $2226-6348 @ 2020$ HRMARS

\section{Problem Statement}

As the early childhood population in Malaysia becomes more diverse with the migrant from another country, multicultural education principles need to incorporate in early childhood education program. Ogletree and Larke (2015) state that children will benefit significantly from early childhood programs that embrace their culture during the early years. The issue of racism as a threat to the unity and harmony that still occur can be prevented with early exposure. This early exposure to cultural diversity will have a positive impact on children in the future from respecting other cultures and societies.

According to preschools, it is a critical element in developing children's socialisation and multicultural awareness of national identity, a national integration that will lead to national unity. However, it would not be possible if educators were more concerned with children's academic achievement. Prosen \& Kuscer (2007) state that early childhood education plays an essential role in the children socialisation process, in particular, it can encourage children to learn social values and develop social skills through building relationships with other children. In line with the goals contained in the National Preschool Standard Curriculum (2017), which sets out the scope of multicultural development, nationalism and patriotism aimed at exposing children to diverse ethnic cultures in Malaysia. Children will be exposed to early knowledge of the uniqueness and diversity of Malaysian culture and to build mutual respect and tolerance for people of all cultures (Majzub, Hashim \& Johannes, 2011)

Racial issues in the country are still unintentionally affecting children's reaction to their lives. Teachers, therefore, play an essential role in educating children about the world around them and providing them with the tools they need to succeed, members of the community. Teachers need to believe in their own culture and diversity in order to effectively plan multicultural education programs for children (Karuppiah \& Berthelsen, 2011). Children need guidance, and when there are teachers on issues related to race and diversity, children not only miss valuable lessons, but they unknowingly find this to be a topic they do not need attention (Vittrup, 2016).

\section{Literature Review}

Multicultural knowledge includes knowledge about the values, worldview, and social norms of both one's own and other cultures (Sue \& Sue, 2003). Besides, multicultural education creates equal educational opportunities for students from diverse cultural groups in order to help all students to acquire the knowledge, attitudes, and skills needed to function effectively in society and to communicate with people from diverse groups Crowder (2013). Multicultural education and global education share essential goals. Global education can enable students to gain crosscultural competency and understandings of global culture (Diaz, 2001). In order to emulate the challenges of $21^{\text {st }}$-century education, children should not underestimate the impact of implementing global readiness elements through teaching and learning activities. The concept of global readiness can be better understood by expanding the skills and communication without borders and making global readiness education more interactive and interdependent. 
Schools are the first space in which the child has social contact with different groups of children from different experiences and backgrounds. In schools, they learn to share, to live with and develop mutual respect (Vinagre, 2019). The school has a vital role in promoting knowledge about different cultures, promoting respect and acceptance in society. It can be seen as a microsociety were children, with positive intervention from teachers, build a society of the future with respects of differences between people. Preschool is essential for the development of young children since they are exposed to explore and learn about the world and experiment values different from their home. The teacher can be a source of inspiration and motivation for the students. The personality of the teacher becomes a reflective surface for children. Thus, teachers have a great responsibility to produce the next generation of character, culture, and moral ( Nikawanti, 2017)

Implementation of multicultural education is a lifelong process in character development. The character development of children is an effort that should involve all parties both the family, school, and community. Therefore, all three components (family, school, and community) should work synergistically. Global readiness education covers eight aspects which are (a) cultural diversity (b) information and technology skills (c) language (d) thinking skills (e) financial literacy (f) security (g) communication and (h) environment. Global readiness education emphasis on cultural diversity should include the (Reimers, 2009) teaching of several foreign languages, numerous social sciences, and the value of a positive attitude toward cultural differences. The component of global readiness is appropriately applied to the traditional curriculum that encompasses the physical, social, emotional, moral, and creative dimensions. (Majzub, 2013; Majzub and Hamidah, 2014).

Sustainable Development Goals (SDGs) is analogous with Puchta (2012) that connect with the needs of the new millennium demands knowledge of global readiness that encompasses cultural, technological, competency, environmental thinking skills and emotional intelligence. Sustainable Development Goals (SDGs) concept self-same with Malaysia Education Blueprint 2013-2025 whereas the transformation of educational system aim to equip individuals holistically, with the competitive, quality and integrated manner through the world-class education system (Ministry of Education, 2017).

A solid foundation of global readiness is crucial to offer educational options for more exposure regarding the real world, especially involving diversity and multiculturalism. Multiculturalism is a way of thinking that it appreciates and respects other perspectives, thus helps future generations to control their lives and prosper the future. For that matter, children must be familiar with the elements of global readiness in the social, economic and environmental contexts in order to be able to apply relevant knowledge, skills and values to become a global player that impacts the multicultural community 


\section{Methodology}

This study focuses on the quantitative data collected on preschool children aged six years old from four zones: Zone 1 (Perlis, Kedah, Pulau Pinang), Zone 2 (N. Sembilan, Melaka, Johor), Zone 3 (Perak, Selangor, Wilayah Persekutuan) and Zone 4 (Kelantan, Terengganu, Pahang),

The sample consisted of 754 preschool children from the four zones. The data was analysed using SPSS 18. Descriptive statistics analysis included percentage (\%), mean, and standard deviation.

\section{Instrument}

The study uses a set of written questionnaires. The instrument is intended to explore the global readiness of preschool children, and questions related to diversity and multiculturalism is one of the cross-sections in the instrument. The interpretation of the mean score and data analysis was based on the data obtained from questionnaires that were distributed for the four zones.

\section{Findings}

Based on the study conducted for 754 preschool children age six years old in the four zones, there is a significant improvement toward preschool student's knowledge of diversity and multiculturalism for global readiness.

Table 1

Percentile Respondents by Zones

\begin{tabular}{lcc}
\hline \multicolumn{1}{c}{ Zone } & N & Per cent (\%) \\
\hline Zone1 (Perlis, Kedah, Pulau Pinang) & 195 & 25.9 \\
Zone 2 ( N.Sembilan, Melaka, Johor) & 198 & 26.3 \\
Zone 3 ( Perak, Selangor, Wilayah & 190 & 25.2 \\
Persekutuan) & & \\
Zone 4 ( Kelantan, Trengganu, Pahang) & 171 & 22.7 \\
$\quad$ Total & $\mathbf{7 5 4}$ & $\mathbf{1 0 0}$ \\
\hline
\end{tabular}

A total of 754 respondents comprising six-year-olds children were involved in this study. Table 1 shows that the number of respondents involved by zones is $25.9 \%$ ( $N=195)$ from zone 1 (Perlis, Kedah, Pulau Pinang), 26.3\% ( $N=198)$ from zone 2( N.Sembilan, Melaka, Johor), 25.2\% $(\mathrm{N}=190)$ from zone 3 ( Perak, Selangor, Wilayah Persekutuan) and 22.7\% ( $N=171)$ from zone 4( Kelantan, Trengganu, Pahang)

The item diversity and multiculturalism divided into four aspects which are cultural knowledge of different ethnic groups, geographical knowledge of different countries, mutual respect towards other and communication skills with friends from various countries. 
INTERNATIONAL JOURNAL OF ACADEMIC RESEARCH IN PROGRESSIVE EDUCATION AND

DEVELOPMENT

Vol. 9, No. 4, 2020, E-ISSN: $2226-6348$ @ 2020 HRMARS

Table 2

Aspects of Diversity and Multiculturalism Knowledge

\begin{tabular}{lccc}
\hline Aspects & Mean & Std. & $\mathrm{t}$ \\
\hline Cultural knowledge of different ethnic groups & .855 & .196 & 119.229 \\
Geographical knowledge of different countries & .665 & .282 & 64.780 \\
Mutual respect for other & .914 & .198 & 126.295 \\
Communication skills with friends from various countries & .911 & .183 & 136.314 \\
\hline
\end{tabular}

The findings in table 2 revealed that the highest mean for four aspects are mutual respect towards other $(m=.914, S D=.198)$ followed by communication skills with friends from various countries (mean=.911, SD=.282) and cultural knowledge of different ethnic groups (mean=.851). However, geographical knowledge of different countries gained the lowest mean value (mean=.655, SD=.282) in this finding.

\section{Aspect 1: Cultural Knowledge of Different Ethnic Groups}

Table 3

Items in Cultural Knowledge of Different Ethnic Groups

\begin{tabular}{|c|c|c|c|c|}
\hline \multirow[t]{2}{*}{ Item } & \multicolumn{4}{|c|}{ Percentage(\%) } \\
\hline & Yes & $\mathrm{N}$ & No & $\mathrm{N}$ \\
\hline Match the house of worship with religion - Masjid (Islam ) & 96.3 & 726 & 3.7 & 28 \\
\hline Match the house of worship with religion - Gereja (Kristian) & 84.4 & 636 & 15,6 & 118 \\
\hline Match the house of worship with religion - Tokong (Buddha) & 70.3 & 530 & 29.7 & 224 \\
\hline Match the house of worship with religion - Kuil ( Hindu ) & 70.4 & 531 & 29.6 & 223 \\
\hline Matching wedding photos Malay races & 95.4 & 719 & 4.6 & 35 \\
\hline Matching wedding photos Indian races & 90.6 & 683 & 9.4 & 71 \\
\hline Matching wedding photos Chinese races & 91.2 & 688 & 8.8 & 66 \\
\hline
\end{tabular}

Table 3 shows seven items that need to be answered on the aspect of Cultural Knowledge Of Different Ethnic Groups by the children aged six-year-olds. The highest score for the correct answer (YES) are match the house of worship with religion (Islam) with $96.3 \%$ ( $N=726)$. Most of the children scored very good in 3 item matching wedding photos with 1) Malay $(95.4 \%, N=719)$, 2) India $(90.6 \%, N=683), 3)$ Chinese $(91.2 \%, N=688)$. The average score for the correct answer, for the item, match the house of worship with a religion (Christian) with $84.4 \%(N=636)$. However, the lowest score for all items are matching the house of worship with a religion (Buddha) with $70.3 \%(\mathrm{~N}=530)$ 
INTERNATIONAL JOURNAL OF ACADEMIC RESEARCH IN PROGRESSIVE EDUCATION AND

DEVELOPMENT

Vol. 9, No. 4, 2020, E-ISSN: $2226-6348$ @ 2020 HRMARS

Aspect 2: Geographical Knowledge of Different Countries

Table 4

Items in Geographical Knowledge of Different Countries

\begin{tabular}{lcc|cc}
\hline \multirow{2}{*}{ Item } & \multicolumn{4}{c}{ Percentage (\%) } \\
\cline { 2 - 5 } & Yes & $\mathrm{N}$ & No & $\mathrm{N}$ \\
\hline Select Different Cities outside Malaysia (Mecca) & 74.3 & 560 & 25.7 & 194 \\
Select Different Cities outside Malaysia (Kuala Lumpur) & 69.4 & 523 & 30.6 & 231 \\
Select Different Cities outside Malaysia (New York) & 66.7 & 503 & 33.3 & 251 \\
Select Different Cities outside Malaysia (Bangkok) & 64.3 & 485 & 35.7 & 269 \\
A house that does not exist where you live (Igloo) & 58.4 & 440 & 41.6 & 314 \\
A house that does not exist where you live (Pyramid) & 58.4 & 440 & 46.3 & 349 \\
A house that does not exist where you live (wooden house) & 53.7 & 405 & 46.3 & 349 \\
\hline
\end{tabular}

Table 4 shows seven items that need to be answered on the aspect of Geographical Knowledge of Different Countries. The highest score for the correct answer (YES) Selects Different Cities outside Malaysia (Mecca) with $74.3 \%$ ( $N=560)$. The average score for the correct answer (Yes) is select different cities outside Malaysia (Kuala Lumpur) with 69.4\% ( $N=523$ ), select different cities outside Malaysia (New York) with 66.7\% ( $\mathrm{N}=593$ ), select different cities outside Malaysia (Bangkok) with 64.3\% ( $\mathrm{N}=485)$. The lowest score for all items are for question $\mathrm{A}$ house that does not exist where you live (wooden house) with $53.7 \%(\mathrm{~N}=405)$

\section{Aspect 3: Mutual Respect Towards Others}

Table 5

Items in Mutual Respect Towards Other

\begin{tabular}{lccc|cr}
\multicolumn{1}{c}{ Item } & \multicolumn{4}{c}{ Percentage(\%) } \\
\cline { 2 - 5 } & Yes & $\mathrm{N}$ & No & $\mathrm{N}$ \\
\hline Match the festival with pictures (Iban) & 91 & 686 & 9.0 & 68 \\
Match the festival with pictures (India) & 89.1 & 672 & 10.9 & 82 \\
Match the festival with pictures (Cina) & 90.8 & 685 & 9.2 & 69 \\
Match the festival with pictures (Melayu) & 95 & 716 & 5.0 & 38 \\
Match the words to the image(Selamat Hari Raya) & 92.2 & 695 & 7.8 & 5.9 \\
Match the words to the image(Deepavali) & 91.2 & 688 & 8.8 & 66 \\
Match the words to the image(Selamat Tahun baru Cina) & 91 & 686 & 9 & 68 \\
\hline
\end{tabular}

The findings in Table 5 revealed that children scored the highest percentage in the aspect of mutual respect towards other on Match the festival with pictures (Melayu) with 95\% ( $\mathrm{N}=715$ ) followed with 92.2\% ( $\mathrm{N}=695$ ) on Match the words to the image (Selamat Hari Raya), 91.2\% ( $\mathrm{N}=688$ ) on Match the words to the image(Deepavali), $91 \%(\mathrm{~N}=686)$ on Match the festival with pictures (Iban). However, children scored lower percentages on Match the festival with pictures (India) with 89.1 $(\mathrm{N}=672)$ 
INTERNATIONAL JOURNAL OF ACADEMIC RESEARCH IN PROGRESSIVE EDUCATION AND

DEVELOPMENT

Vol. 9, No. 4, 2020, E-ISSN: $2226-6348$ @ 2020 HRMARS

Aspect 4: Communication Skills with Friends from Various Countries

Table 6

Items in Communication Skills with Friends From Various Countries

\begin{tabular}{lcc|cc}
\hline \multicolumn{1}{l}{ Item } & \multicolumn{3}{c}{ Percentage(\%) } \\
\cline { 2 - 5 } & Yes & $\mathrm{N}$ & No & $\mathrm{N}$ \\
\hline $\begin{array}{l}\text { A proper greeting when meeting with friends from } \\
\text { abroad }\end{array}$ & 89.7 & 676 & 10.3 & 78 \\
- hello & & & & \\
Which attitude is best when you meet friends - say hello & 95.4 & 719 & 4.6 & 35 \\
Words when friends help you - Thank you & 92.2 & 695 & 7.8 & 59 \\
Always smiling - smiley emoji & 96.3 & 726 & 3.7 & 28 \\
The right words when receiving a gift - Thank you & 82.1 & 619 & 17.9 & 135 \\
\hline Table 6 above revealed that children scored the highest percentage in the aspect of \\
Communication Skills with Friends from Various Countries. Items with the highest percentages of \\
95.2\% were always smiling. For the lowest communication aspect of the item, 81.1\% was the \\
right word when receiving the gift.
\end{tabular}

\section{Discussion}

Based on a study conducted with 754 preschool children, the findings show that preschool children know the culture of different ethnic groups based on the picture given in the written questionnaire with a total mean $=.855$. Besides, through the picture, preschool children able to discern the diverse culture in this country

However, the mean score in communication skills with friends from various countries shows that children can communicate well with their peers in simple language with mean score .911. This finding in parallel with Noor Aini Ahmad, (2014) who avows that the knowledge of children's language is influenced by symbolic elements, their environment and culture. This is proven why preschool children show a significant comprehension usage of several languages based on the picture as a representative element used to convey message and meaning

Encounter perplexity to identify children skills affects the finding of language because of preschool children unable to decide which language used to communicate with friends from other countries.

Above all, preschool children are capable of recognising and convey mutual respect towards others. Conclusively shows a great deal in this research. Preschool children show an immense knowledge on how to communicate and behave accordingly with a sense of respect towards others. Respect aspect shows the highest score in this research (mean=.914) which display preschool children's understanding of how to communicate and behave accordingly with a sense of respect towards others. However, this is contrasting to Sennett (2004); George (2009), where he describes children is not seen as a full human being whose presence of respect matters. 
However, children fathom the knowledge for the geography of different countries are the lowest mean score (mean=.655). Preschool children learn about geography mostly from television and social platform. Unfortunately, televised displays often lack the dynamic and perceptual richness of everyday life, resulting in potentially weaker mental representations. These perceptual differences may make it particularly difficult for preschool children to differentiate information and transfer knowledge from television to reality. (Schmitt, 1997: Anderson et al., 2012)

The finding of questionnaire analysis shows diversity and multiculturalism in global readiness education is useful in the learning process, thus enhanced preschool children's knowledge, attitudes and personality. It also shows that the techniques and activities play essential catalysis in succouring them to understanding better about global readiness education.

In addition, the aspects included in the questionnaire are indeed helpful and practical to give preschool children a better apprehension and contemplate things in a more straightforward, more comfortable and more practical way. It clearly demonstrates that the implementation of diversity and multiculturalism in global readiness education have shown positive outcomes for preschool children in Selangor district schools.

Indisputably, the questions designed has proven useful to equip preschool children with general knowledge of diversity and multiculturalism in global readiness education.

\section{Conclusion}

The findings show that preschool children have a solid foundation of knowledge in diversity and multiculturalism for global readiness education. Four aspects of basic knowledge assessed related to diversity and multiculturalism give a glimpse of preschool children capability to assimilate the knowledge in diversity and multiculturalism. Preschool children cultural knowledge of different ethnic groups, geographical knowledge of different countries, mutual respect towards other and communication skills with friends from various countries forecast a propitious vision of promising future generation.

Based on these findings, it is clear that the implementation of knowledge in diversity and multiculturalism global readiness education is valid and has an impact on making the learning skills practical and elementary among preschool children. This will gradually give an insight into children contemporary knowledge on diversity and multiculturalism plus encourage preschool teachers to implement global readiness education in school.

As the millennium era is approaching, preschool children should not only equip with academic skills with all the competence to become future global players. Besides, the knowledge of diversity and multiculturalism imparted plenty of adaptive skills for the outside world in line with 21st-century learning. 
INTERNATIONAL JOURNAL OF ACADEMIC RESEARCH IN PROGRESSIVE EDUCATION AND

DEVELOPMENT

Vol. 9, No. 4, 2020, E-ISSN: $2226-6348 @ 2020$ HRMARS

\section{Acknowledgement}

This study is under the University Education Grant (GPU 2018-0036-107-01). Thank you to RMIC and also the Faculty of Human Development, Universiti Pendidikan Sultan Idris.

\section{Corresponding Author}

Azizah Zain, Faculty of Human Development, Sultan Idris University of Education (UPSI),

Malaysia.

Email: azizah.zain@fpm.upsi.edu.my

\section{References}

Crowder, G. (2013). Theories of multiculturalism: An introduction. Cambridge: Polity Press.

Diaz, C. F. (2001). The third millennium: a multicultural imperative for education. In Diaz, C. F. (Ed), Multicultural education in the 21st century (pp. 1-10). New York: Addison-Wesley.

Fam, Q. N. (2015). Relationship between multiculturalism and higher education policy in Malaysia in terms of ethnic diversity and equality. (Bachelor dissertation, Wichita State University, Kansas). Retrieved from https://scholar.googleusercontent.com/scholar?q=cache:biOtFgVM74sJ:scholar.google.co $\mathrm{m}$

George, S. (2009). Too young for respect? Realising respect for young children in their everyday environments. A cross-cultural analysis. Working Paper No. 54. The Hague, The Netherlands: Bernard van Leer Foundation

International Federation of Library Associations and Institutions. Public Libraries. (2001). The public library service: IFLA/UNESCO guidelines for development. München: K.G. Saur.

Karuppiah, N., \& Berthelsen, D. (2011). Multicultural Education: The Understandings of Preschool Teachers in Singapore. Australasian Journal of Early Childhood, 36(4), 3842. doi: $10.1177 / 183693911103600406$

Kymlicka, W. (2012). Multiculturalism: Success, Failure and the Future. Washington, DC: Migration Policy Institute.

Ministry of Education. (2012). Laporan Awal Pelan Pembangunan Pendidikan Malaysia 20132025. Kuala Lumpur: Kementerian Pelajaran Malaysia.

Ministry of Education. (2017). Standard Kurikulum Prasekolah Kebangsaan Malaysia. Kuala Lumpur: Kementerian Pendidikan Malaysia.

Ministry of Education. (2016). Malaysia Education Blueprint, Annual Report 2016. Kuala Lumpur: Kementerian Pendidikan Malaysia.

Kassim, K., \& Zakaria. A. (2015). Integrasi Kemahiran Berfikir Aras Tinggi Dalam Pengajaran dan Pembelajaran Matematik: Analisis Keperluan Guru. Prosiding Seminar Education Graduate Regional Conference (EGRC 2015)

Ahmad, N. A. (2014) Language Skills for Children Early Age Integrating Information and Communication Technologies as an Aid in Teaching. Jurnal Pendidikan Bahasa Melayu.

Nikawanti, G. (2017). Multicultural Education for Early Childhood. Proceedings of the 3rd International Conference on Early Childhood Education (ICECE 2016), 58. doi: 10.2991/icece-16.2017.40

Ogletree, Q., \& Larke, J. L. (2010). Implementing Multicultural Practices in Early 
Childhood Education. National Forum of Multicultural Issues Journal Volume 7, Number 1. 2010

Oltman, M. (2012). Natural Wonders: A Guide to Early Childhood for Environmental Educators. Minnesota Children's Museum and the Minnesota Office of Environmental Assistance. Minnesota: Minnesota Children's Museum.

Puchta, H. (2012) Developing Thinking Skills in the Young Learners' Classroom. Cambridge: Cambridge University Press.

Prosen, S., \& Pergar Kušcer, M. (2007). The Preschool teacher as an object of attachment. In Ross, A. Citizenship Education in Society. London.

Reimers, F. (2009). 'Global competency' is imperative for global success. The Chronicle of Higher Education, 55(21), A29.

Majzub, R. M., Hashim, S., \& Johannes, H. E. (2011). Cultural awareness among preschool teachers in Selangor, Malaysia Cultural awareness among preschool teachers in Selangor, Malaysia. Procedia - Social and Behavioral Sciences, 15, 1573-1579. doi: 10.1016/j.sbspro.2011.03.333

Mahzub, R. M. (2012). Identiti Guru: Cabaran dan Hala Tuju. Prosiding Seminar Kebangsaan Profesion Perguruan. Universiti Kebangsaan Malaysia, Bangi, Selangor, hlm. 110-121.

Sue, D. W., \& Sue, D. (2003). Counseling the culturally diverse: Theory and practice (4th ed.). New York: Wiley

UNESCO. (2016). Education for All 2000-2015: Achievement and Challenges. United Nations Educational, Scientific and Cultural Organization.

United Nations. (2015). Transforming our World: The 2030 Agenda for Sustainable Development. Vinagre, J. (2019). Cultural diversity in preschool Development of teachers' educational tools in multicultural classes. Disertation

Vittrup, B. (2016). Early Childhood Teachers' Approaches to Multicultural Education \& Perceived Barriers to Disseminating Anti-Bias Messages. Multicultural Education Studies, 9(2). doi: 10.14328/mes.2016.6.30. 